J. Clin. Chem. Clin. Biochem.

Vol. 24, 1986, pp. 283-292

(C) 1986 Walter de Gruyter \& Co. Berlin - New York

\title{
The Isoelectric Focusing of Creatine Kinase Variants: I. The Heterogeneity of Creatine Kinase in Human Heart Cytosol and Mitochondria
}

\author{
By E. SiragEldin
}

Abteilung für Klinische Chemie der Medizinischen Universitätsklinik, Hamburg

G. Gercken

Institut für Biochemie und Lebensmittelchemie der Universität Hamburg

K. Harm

Zentrallaboratorium des Allgemeinen Krankenhauses Heidberg, Hamburg and

K. D. Voigt

Abteilung für Klinische Chemie der Medizinischen Universitätsklinik, Hamburg

(Received April 1/ October 31, 1985//January 7, 1986)

Summary: Creatine kinase isoenzymes in cytosolic and mitochondrial fractions from human cardiac tissues were studied by analytical and preparative isoelectric focusing (IEF), electrophoresis and immunoinhibition. Analytical IEF on agarose gels revealed many creatine kinase variants in human cardiac cytosol prepared by extraction with a hypotonic medium. The bands located at approximately $\mathrm{pH} 5.5$ were shown to contain creatine kinase-MB and minute creatine kinase-BB bands by electrophoresis. Two bands which focused closely together in IEF ( $\mathrm{pH} 6.85-7.0$ ) showed an electrophoretic migration pattern similar to creatine kinaseMM. One of them (IP 6.85) showed a complete inhibition by anti-creatine kinase-M antibodies, whereas the other showed only $50 \%$ inbibition.

Increasing the salt concentration of tris- $\mathrm{HCl}(0.1 \mathrm{~mol} / \mathrm{l})$ in the extraction medium resulted in additional creatine kinase variants. They were characterized by high alkaline isoelectric points and were not inhibited by anti-creatine kinase-M antibodies. These variants corresponded to two cathodic bands in electrophoresis. The treatment of washed mitochondria with phosphate buffer resulted in a release of mitochondrial variants with different isoelectric points, as shown by analytical IEF in agarose gels.

The same pattern wạs obtained by using preparative IEF. Variants with high alkaline isoelectric points gave rise to two cathodic bands upon electrophoresis. These two bands resembled those present in cytosol after extraction with high salt concentration. No complete inhibition with anti-creatine kinase-M was observed in any of the eluates.

The mitochondrial variants exhibitèd different affinities towards creatine phosphate and ADP. Variants with higher alkaline isoelectric points showed lower $K_{\mathrm{m}}$-values for these substrates than those with less alkaline isoelectric points.

Isoelektrische Fokussierung von Kreatinkinase-Varianten: I. Die Heterogenität der Kreatinkinase im Cytosol und in den Mitochondrien des menschlichen Herzens

Zusammenfassung: Kreatinkinase-Isoenzyme in cytosolișchen und mitochondrialen Fraktionen von menschlichem Herzgewebe wurden durch analytische und präparative isoelektrische Fokussierung (IEF) sowie

J. Clin. Chem. Clin. Bioghem. / Vol. 24, 1986 / No. 5 
Elektrophorese und Immuninhibitionstest untersucht. Die analytische isoelektrische Fokussierung auf Agarosegel zeigte verschiedene Kreatinkinase-Varianten im menschlichen Herzcytosol, das mit hypotonischem Medium extrahiert wurde. In den bei pH 5,5 lokalisierten Fraktionen waren Kreatinkinase-MB- und schwache Kreatinkinase-BB-Banden in der Elektrophorese nachweisbar. Zwei Banden, welche in der IEF dicht zusammenlagen ( $\mathrm{pH}$ 6,85-7,0), wanderten in der Elektrophorese ähnlich wie Kreatinkinase-MM. Eine der beiden (IP 6,85) zeigte eine komplette Hemmung durch anti-Kreatinkinase-M-Antikörper, die andere wurde dagegen nur $\mathrm{zu} 50 \%$ gehemmt. Eine Erhöhung der Tris- $\mathrm{HCl}-\mathrm{Konzentration}(0,1 \mathrm{~mol} / \mathrm{l}) \mathrm{im}$ Extraktionsmedium führte zu zusätzlichen Kreatinkinase-Varianten. Diese waren charakterisiert durch ihre stark alkalischen isoelektrischen Punkte und wurden nicht durch anti-Kreatinkinase-M-Antikörper gehemmt. Diese Varianten ergaben in der Elektrophorese zwei kathodisch wandernde Banden. Die Behandlung von gewaschenen Mitochondrien mit Phosphatpuffer führte zur Freisetzung von mitochondrialen Varianten, die verschiedene isoelektrische Punkte bei der analytischen isoelektrischen Fokussierung auf Agarosegel aufwiesen. Das gleiche Muster erhielt man bei der präparativen IEF. Varianten im stark alkalischen Fokussierungsbereich findet man als zwei kathodisch wandernde Banden in der Elektrophorese wieder. Diese beiden Banden ähnelten denen des Cytosols, die bei der Extraktion mit hohen Salzkonzentrationen auftraten. Eine vollständige Hemmung mit anti-Kreatinkinase-M wurde bei keinem der Eluate beobachtet. Die mitochondrialen Varianten zeigten außerdem verschiedene Affinität zu Kreatinphosphat und ADP. Varianten mit stark alkalischen isoelektrischen Punkten hatten niedrigere $K_{\mathrm{m}}$-Werte für diese Substrate als solche mit schwächer alkalischen isoelektrischen Punkten.

\section{Introduction}

The creatine kinase enzyme (EC 2.7.3.2) which catalyses the synthesis of ATP from creatine phosphate and ADP, is widely distributed among muscle and brain tissues. The cytoplasm of mammalian tissues contains three dimeric forms of creatine kinase namely, creatine kinase-MM, creatine kinase-MB, and creatine kinase-BB. These are formed by a combination of two different types of enzyme subunits: muscle type (M) and brain type (B).

It is also accepted that a significant proportion of cellular creatine kinase is located in the mitochondria of the cardiac muscle $(1-6)$.

Recently, considerable discrepances have been noticed concerning the heterogeneity of both cytosolic and mitochondrial creatine kinase. Because of the ambiguity concerning the number of native and serum-induced creatine kinase-MM subspecies, a study of the heterogeneity of bovine heart muscle was performed in 1982 (unpublished data), followed by a brief description of a sensitive isoelectric focusing method on Isogel agarose for the estimation of creatine kinase-MB in human sera (7).

George et al. (8) reported that purified creatine kinase-MM from tissue exists as a single form, but upon release into the plasma exhibits three forms. As this study was in progress, Guslits \& Jacobs (9), in contrast to the above authors, reported the existence of twenty one subspecies of creatine kinase-MM from human muscle, which were resolved by isoelectric focusing (as a result of the combination of 6 subspe- cies). Because their study was restricted to creatine kinase-MM, a complete creatine kinase isoenzyme pattern in both cytosol and mitochondria was not considered.

With regard to the mitochondrial creatine kinase, Hall et al. (10) showed that beef heart mitochondrial creatine kinase is composed of a fast cathodical migrating $\mathrm{CKm} 2$ and another one with a slower ca= thodal migration relative to creatine kinase-MM on cellulose acetate electrophoresis. In addition, they showed that creatine kinase $\mathrm{m} 2$ can be converted to creatine kinase $\mathrm{m} 1$ in the presence of 2-mercaptoethanol. Further, Kanemitsu et al. (11) suggested that mitochondrial creatine kinase may exist in three forms. Desjardins (12) isolated a creatine kinase designated as creatine kinase- $Z$ from the $600 \mathrm{~g}$ particulate fraction of the homogenate of human heart. This form migrated cathodally to creatine kinase-MM on agarose electrophoresis and was not inhibited by antibodies directed against human creatine kinase-MM and creatine kinase- $\mathrm{BB}$. The creatine kinase- $Z$ was found to exist in two molecular forms. In contrast, Grace et al. (13) and Roberts \& Grace (14), using different purification procedures, claim to have found only mitochondrial creatine kinase composed of two subunits of an equal molecular weight of 41000 in both human and canine mitochondria.

In the present paper, we describe the heterogeneity of both cytosolic and mitochondrial creatine kinase in human myocardial muscle as revealed by preparative and analytical isoelectric focusing methods. 


\section{Eppendorf-}

Diagnosticasysteme haben vieles gemeinsam -

angefangen vom Netzstecker bis hin zu unserem Knowhow auf dem Gebiet der Entwicklung und Fertigung hochwertiger Analysengeräte.

Ein für alle Einsatzgebiete in der klinischen Chemie gleichermaßen geeignetes Gerät zu entwickeln, ist auch uns noch nicht gelungen. Deshalb bieten wir verschiedene Systeme, zugeschnitten auf ihre individuellen Bedürfnisse.

Für welches Eppendorf Analysensystem Sie sich auch entscheiden, unser bewährtes, auf das klinischchemische Labor spezialisierte Service- und Beratungsteam ist für alle da!

\section{EASY -} sichere Ergebnisse rund um die Uhr.

Das EASY-System für Notfallanalysen und Kleinserien ist 24 Stunden am Tag einsatzbereit - bei minimalem Bedienungsaufwand. Die wichtigsten Enzym-, Substrat- und Elektrolytbestimmungen werden als gebrauchsfertige Küvettentests von Merck geliefert.

Nach Zuführung von Probe und EASY-Test-Küvetten arbeitet das System völlig selbständig, schnell und zuverlässig.

\section{EPOS ${ }^{\circledR}$ -}

für Routine und Spezialverfahren.

Das selektive Analysensystem EPOS ${ }^{-}$- ideale Kombination von Analysengerät und Microcomputer - ist problemlos in jede Labororganisation zu integrieren. Neben üblichen RoutineVerfahren sind bei hohem Durchsatz auch Spezialverfahren, z.B. EMIT ${ }^{\oplus}$ möglich. Variable Methodenparameter, stationäre Küvetten und geringe Reagenzvolumina sind weitere Faktoren für flexiblen und wirtschaftlichen Betrieb.

\section{ERIS -}

das schnelle System für I Routine-Methoden.

Mit ERIS $\otimes$ bestimmen Sie zu 23 Parameter selektiv a einer Probe - als Einzelbestimmung oder als Profi schnell und sicher. Notfallproben? Kein Problem! Bereits nach 10-15 Minute liegt das Resultat für alle angeforderten Tests vor unverändert hohem

Analysen-Durchsatz. Die v Merck entwickelten ERIS Tests sind speziell auf die fordernisse des Systems a gestimmt.

\section{Bitte rufen Sie uns an,}

wir diskutieren mit Ihnen o optimale Lösung für Ihr La
Eppendorf Gerätebau Netheler + Hinz GmbH Postfach 650670 2000 Hamburg 65 Telefon (040) 538 01-0 Telex $2174315 d$ 

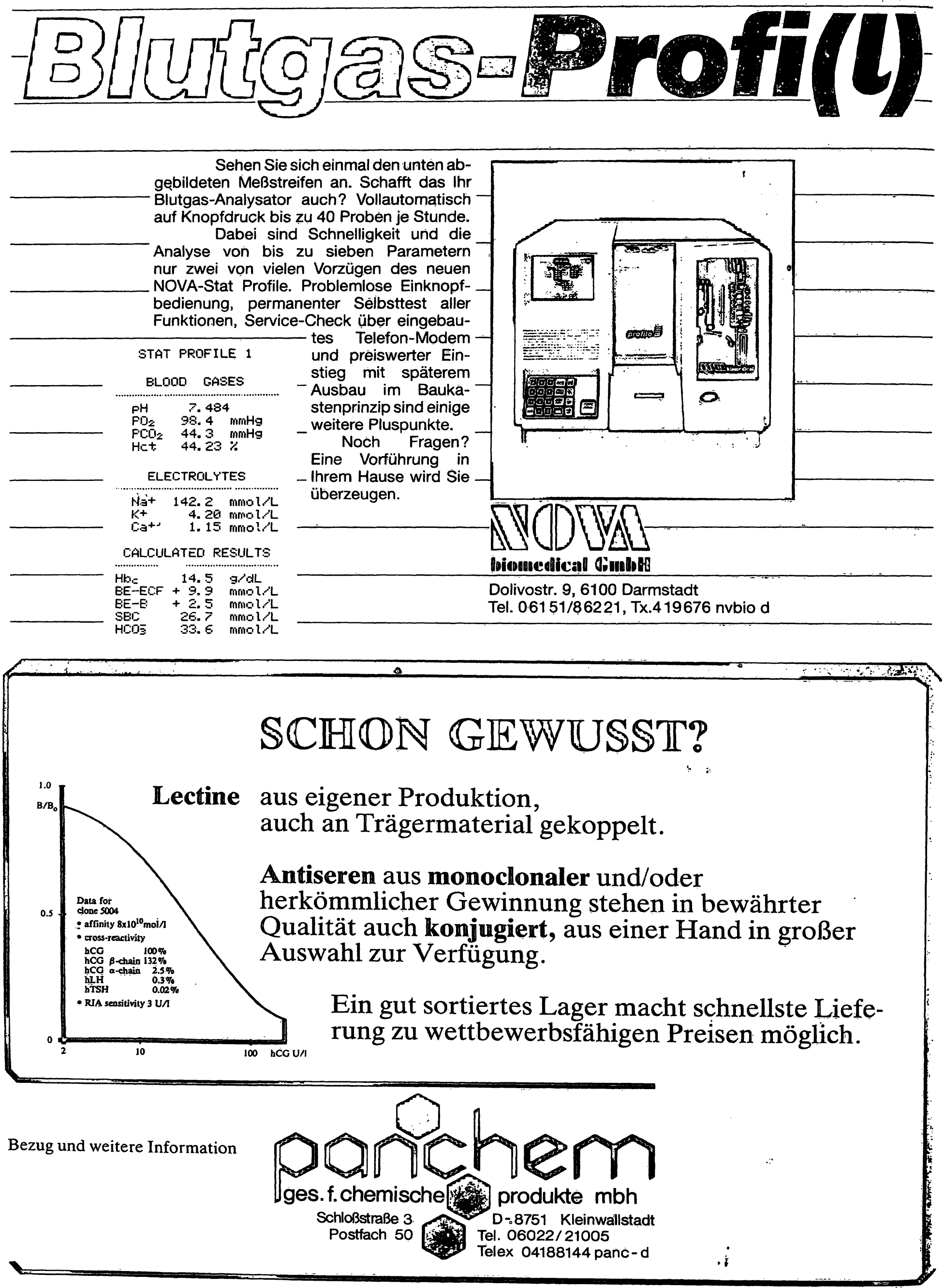


\section{Materials and Methods}

\section{Materials}

Dithiothreitol, ethylenediamine tetraacetic acid (EDTA), ethyleneglycol-bis-( $\beta$-aminoethyl ether) $\mathbf{N}, N_{,}, N^{\prime}, N^{\prime}$-tetraacetic acid (EGTA), tris(hydroxymethyl)aminomethane, CPK-ISOTROL, sorbitol and nitroblue tetrazolium were obtained from Sigma Chemie, München. Creatine kinase NAC-activated and creatine kinase-MB NAC-activated test kits and meldola blue were purchased from Boehringer, Mannheim. Isogel agarose-EF, Ampholine and Gelbond were obtained from LKB, Bromma. Agarose-IEF and Pharmalyte 6.5-9.0 were obtained from Pharmacia, Uppsala.

\section{Tissue extractions}

Modifications of already described methods $(1,6,15)$ were used for the preparation of mitochondrial creatine kinase. All procedures were carried out in an ice bath.

Human heart tissue was obtained four hours after death, and papillary muscle was obtained during open heart surgery for mitral valve replacement. All tissues were immediately removed and placed in cold extraction medium containing $0.25 \mathrm{mmol} / \mathrm{l}$ sucrose, $0.1 \mathrm{mmol} / 1 \mathrm{EGTA}, 0.2 \mathrm{mmol} / 1$ dithiothreitol and 0.01 $\mathrm{mol} / \mathrm{l}$ tris- $\mathrm{HCl}, \mathrm{pH} \mathrm{7.4,} \mathrm{washed} \mathrm{to} \mathrm{remove} \mathrm{blood,} \mathrm{trimmed} \mathrm{of}$ fat, and minced with scissors. They were then passed through a pre-cooled meat grinder or chopped with a knife (papillary muscle). The ground tissue was homogenized in a Waring Blender in extraction medium ( $5 \mathrm{ml} / \mathrm{g}$ tissue, myocardium) or with a Potter-Elvehjem homogenizer in extraction medium (10 $\mathrm{ml} / \mathrm{g}$ tissue, papillary muscle). To remove large debris and any remaining cells, centrifugation was performed at $1000 \mathrm{~g}\left(4^{\circ} \mathrm{C}\right)$ for $10 \mathrm{~min}$ and the supernatant fraction was filtered through four layers of cheese cloth. The supernatant was again centrifuged at $20000 \mathrm{~g}$ for $20 \mathrm{~min}$ at $4{ }^{\circ} \mathrm{C}$, decanted and centrifuged again as stated above to obtain the cytosol fraction.

The sediment containing the mitochondria was washed 5 times in the above extraction medium. The mitochondrial creatine kinase was extracted by gentle agitation in $83 \mathrm{mmol} / 1$ phosphate buffer containing $0.2 \mathrm{mmol} / \mathrm{l}$ dithiothreitol, $\mathrm{pH} 7.4$, at $4{ }^{\circ} \mathrm{C}$ overnight. The extract was centrifuged at $100000 \mathrm{~g}$ for $30 \mathrm{~min}$ at $4^{\circ} \mathrm{C}$. The supernatant was decanted and stored at $-20^{\circ} \mathrm{C}$.

A portion of human heart tissue was homogenized in the above homogenizing medium containing $0.1 \mathrm{~mol} / 1$ tris- $\mathrm{HCl}$ at $\mathrm{pH} 7.4$. The cytosol fraction was obtained as stated above.

\section{Methods}

\section{Quantitative determination of creatine kinase activities}

The optimized spectrophotometric method based on the recommendations of the German Society for Clinical Chemistry was used to measure total creatine kinase activity (16) with a Hitachi Rate Analyzer at $25^{\circ} \mathrm{C}$.

Creatine kinase-MB was determined at $25^{\circ} \mathrm{C}$ after immunological inbibition of creatine kinase-M subunits by specific anti- $M$ antibodies.

\section{Electroendosmosis-low agarose electrophoresis}

In certain cases, the creatine kinase bands were stained as described for thin-layer isoelectric focusing instead of scanning for fluorescence intensity $(7,17)$.

\section{Preparative isoelectric focusing}

The human heart mitochondrial creatine kinase (extraction I) was concentrated four-fold with an Amicon membrane (type Centricon 10) and dialysed overnight with $1 \%$ Ampholine $\mathrm{pH}$ 6-8.
The preparative isoelectric focusing was performed on an LKB 8100 Ampholine electrofocusing column. The density gradient solution was supplemented with $1 \mathrm{mmol} / 1$ dithiothreitol. The density differences correspond to light and dense solutions containing 5 and $50 \%$ sorbitol, respectively. Ampholines with ranges of $\mathrm{pH} \mathrm{5-7}$ and $\mathrm{pH} 7-9$ were used at a final concentration of $1 \%$ as carrier ampholytes. Dilute phosphoric acid and dilute sodium hydroxide were used as anolyte and catholyte respectively.

The sample was introduced as follows: After layering a few milliliters of the gradient solution over the dense electrode solution, the peristaltic pump was stopped, the connection between the two vessels of the gradient mixture was closed and $3 \mathrm{ml}$ were removed from the dense solution. A few crystals of sorbitol were dissolved in the sample and added to the dense gradient solution, remixed thoroughly and the gradient formation was restarted. The cooling temperature was $10^{\circ} \mathrm{C}$, and the electrical parameters at an LKB 2197 power supply were set as follows: current to maximum and voltage to 1700 volts. The initial 500 volts were set by increasing the power to approximately $5 \mathrm{~W}$.

After 43 hours, $1.5 \mathrm{ml}$ fractions were collected. The pH was measured in each fraction at $22^{\circ} \mathrm{C}$ using a glass electrode (Ingold) and a pH meter (CG820 Schott), calibrated at pH 4.01 and $\mathrm{pH} 7.0$.

\section{Thin-layer isoelectric focusing of creatine kinase isoenymes on} agarose

For thin layer isoelectric focusing, we used an LKB model 2217 Ultrophor. The procedures for the preparation of thin layer gel as described by the manufacturer (18) were applied.

The separation of creatine kinase isoenzymes by isoelectric focusing on Isogel as well as the detection of creatine kinase activity bands were performed according to the method described by SiragEldin et al. (7).

Adenylate kinase interference was tested by performing control reactions in which creatine phosphate, adenosine monophosphate (AMP) and diadenosine pentaphosphate (Ap5A) were omitted.

\section{Results}

The heterogeneity of creatine kinase in cardiac cytosol using $0.5 \mathrm{~mm}$ thin layer isoelectric focusing on Isogel agarose

Figure 1 a shows the analytical isoelectric focusing of human myocardial cytosol resuspended in extraction medium containing different concentrations of tris$\mathrm{HCl}$. Sample A represents the cytosol taken in 0.01 $\mathrm{mol} / \mathrm{l}$ and sample B that in $0.1 \mathrm{~mol} / \mathrm{l}$ tris- $\mathrm{HCl}$. Sample $C$ is a $1: 10$ dilution of sample $B$ with normal saline before IEF. When $2 \mu \mathrm{l}$ of each of cytosol $\mathrm{A}$ and $B$ were applied to analytical Isogel agarose using Ampholine pH 5-8, a considerable number of variants of creatine kinase were observed. Sample B, which was extracted in a 10-fold concentration of tris- $\mathrm{HCl}$, additionally contains other cytosolic and even mitochondrial variants characterized by more alkaline isoelectric points than those observed in sample A. Figure $1 \mathrm{~b}$ shows the migration patterns of cytosolic creatine kinase variants from another 
human heart muscle by analytical isoelectric focusing on Isogel-agarose in the $\mathrm{pH}$-range 5-8. Cytosol D and $E$ were treated as mentioned in figure $1 \mathrm{a}$. Additionally, a mitochondrial creatine kinase extraction (G) was carried out as described in "Methods". Adenylate kinase activity was observed in samples D and $\mathrm{E}$, when creatine phosphate, adenosine monophosphate and diadenosine pentaphosphate were omitted from the reaction medium (fig. $1 \mathrm{c}$ ). However, this activity was completely inhibited with our reac- tion medium, where only creatine phosphate was omitted (fig. $1 \mathrm{~d}$ ).

Five fractions (fig. 1 a) were eluted and the total creatine kinase and residual activities using the immunoinhibition test were determined. The results were plotted logarithmically (fig. $2 \mathrm{a}$ ). The bands with more alkaline isoelectric points (Fraction 1) were not inhibited by anti-creatine kinase-M. Fraction 2, in contrast, showed a $50 \%$ inhibition. Fraction 3 was com-
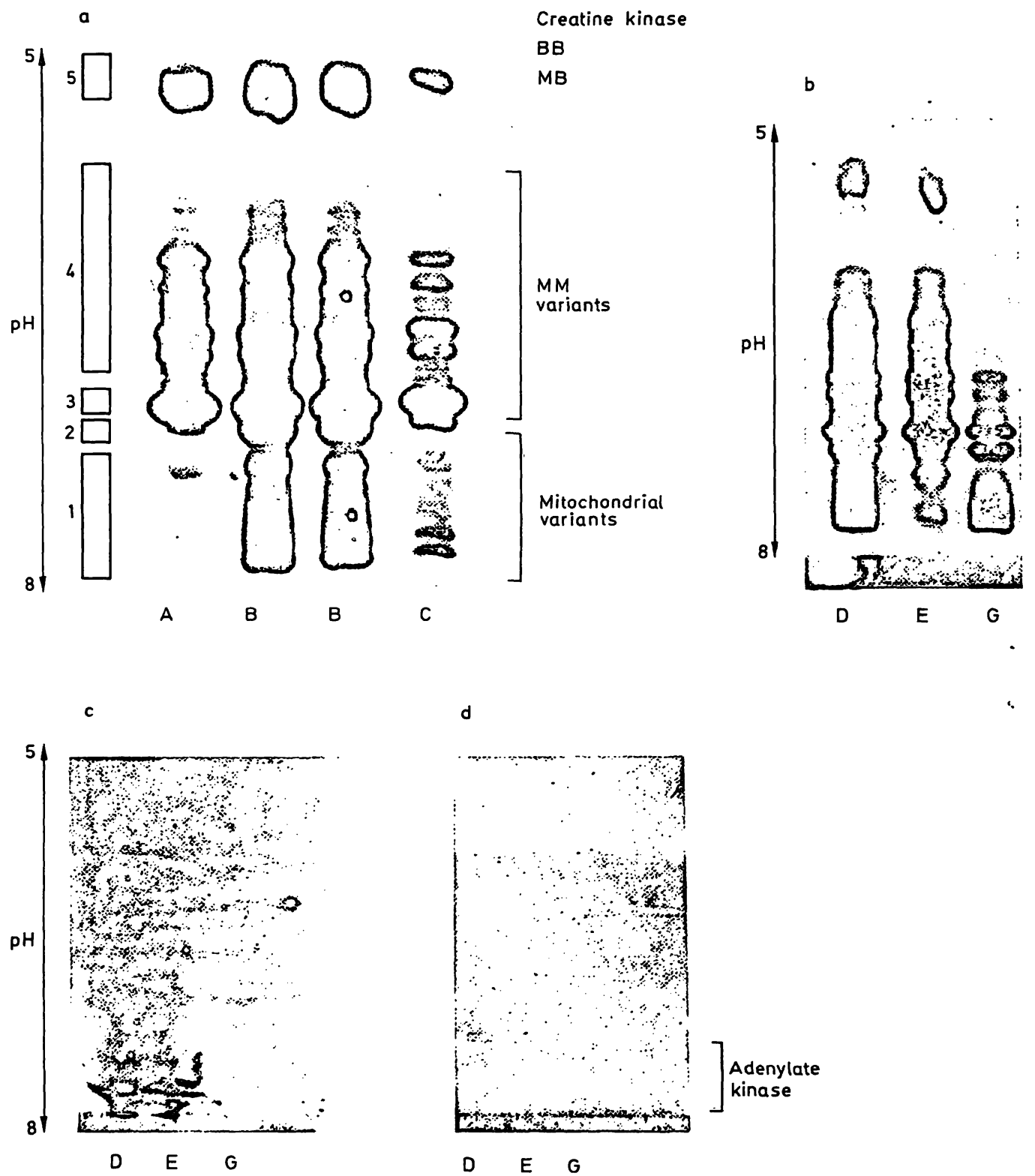

d

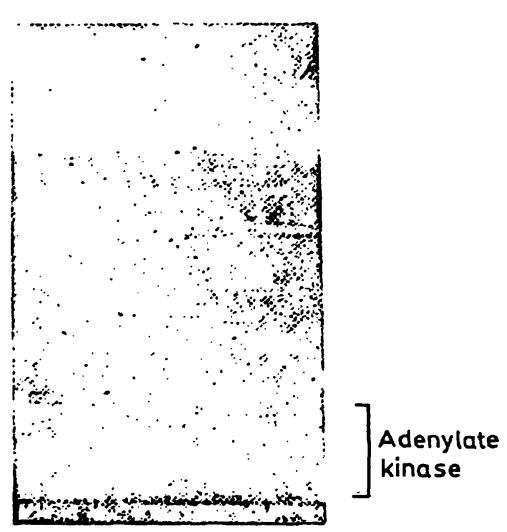

D E G

Fig. 1. a) Cytosol $\mathrm{A}$ and $\mathrm{B}$ were suspended in extraction medium containing $0.01 \mathrm{~mol} / \mathrm{l}$ and $0.1 \mathrm{~mol} / \mathrm{l}$ tris- $\mathrm{HCl}$, respectively. Sample $C$ is a $1: 10$ dilution of sample B with normal saline. Creatine kinase activity bands were made visible by staining with nitroblue tetrazolium and meldola blue.

The numbers on the left side correspond to the five fractions eluted and tested for total creatine kinase and residual creatine kinase acitivity after immunoinhibition by creatine kinase-M-antibodies (see fig. $2 \mathrm{a}$ ).

b) Migration pattern of cytosolic creatine kinase variants from another human heart muscle by analytical isoelectric focusing on Isogel-agarose in the pH-range 5-8. Cytosol $\mathrm{D}$ and $\mathrm{E}$ were treated as mentioned in fig. 1 a. Additionally a mitochondrial creatine kinase extraction $(G)$ was carried out as described in "methods".

c) Adenylate kinase pattern from samples $D$ and $E$ when creatine phosphate, adenosine monophosphate and diadenosine pentaphosphate were omitted from the reaction medium. No adenylate kinase activity was observed in sample $G$.

d) Results obtained from samples D, E and G when creatine phosphate was omitted from the reaction medium. 


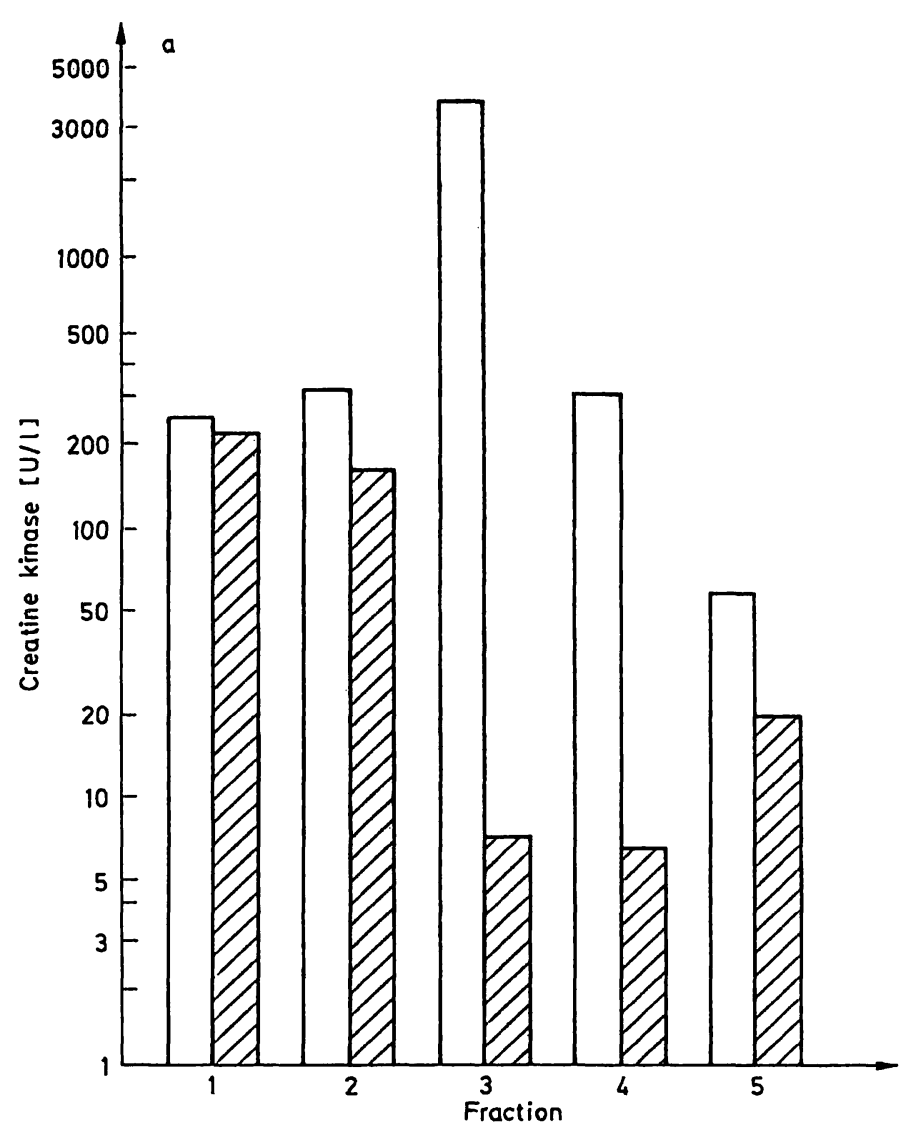

$\oplus^{b}$

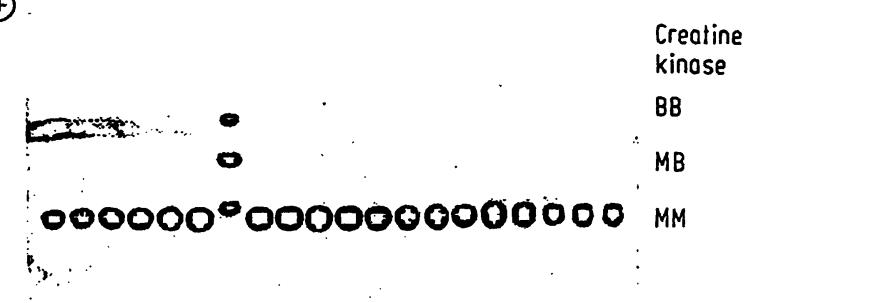

pletely inhibited. In Fraction $4,98 \%$ of the initial activity was inhibited by anti-creatine kinase-M, while in Fraction 5 there was residual activity of $34 \%$.

Fractions corresponding to 3 and 4 (fig. 1 a) were eluted from a preparative isoelectric focusing column, and were analysed for total creatine kinase and residual activity using the immunoinhibition test and electrophoresis. No residual activity was noticed in these fractions, and their application to electrophoresis demonstrated a pattern corresponding to creatine kinase-MM (fig. 2 b). From fractions corresponding to 5 (fig. 1 a), a precipitation of proteins was observed during preparative isoelectric focusing. In spite of this, a clear creatine kinase-MB band was found on both cellulose acetate electrophoresis and analytical isoelectric focusing $\mathrm{pH} \mathrm{5-8} \mathrm{(fig.} 2 \mathrm{c}$ and $2 \mathrm{~d}$ ).

As the result of the relatively low concentration of creatine kinase- $\mathrm{BB}$ and its instability during isolectric focusing, a direct confirmation was not possible. However, when a comparative analytical isoelectric focusing was carried out on a serum sample containing a known high concentration of creatine kinaseBB (fig. 2e), a band corresponding to fraction 5 was also observed (fig. $2 \mathrm{f}$ ). To exclude the possibility of inactivation of the creatine kinase isoenzymes in the post mortem sample, a human papillary muscle was immediately extracted $(0.01 \mathrm{~mol} / \mathrm{l}$ tris $-\mathrm{HCl})$ and the creatine kinase was treated as described above (cytosol A). These results (fig. 3) and those of the post mortem sample (fig. 1 a) were similar.

$\Theta$

c
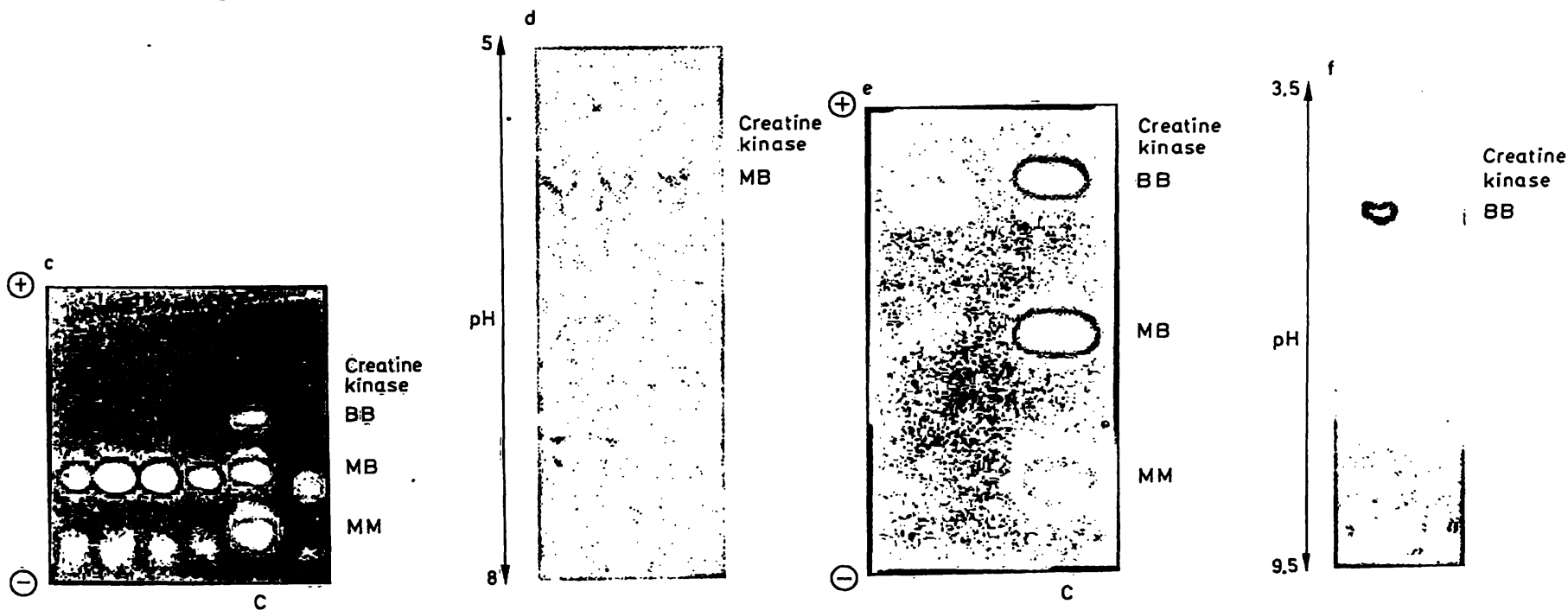

Fig. 2. a) Inhibition of cytosolic creatine kinase activities in fractions $1-5$ (see fig. 1) by creatine kinase-M-antibodies. The results are plotted logarithmically.

$\square$ initial activity, residual activity.

b) Electrophoretic pattern from different Ampholine column eluates corresponding to fractions 3 and 4 (fig. 1 a).

c) Cellulose acetate electrophoretic pattern from different Ampholine column eluates corresponding to fraction 5 (fig.

1a). Creatine kinase activity bands were made visible by fluorescence staining.

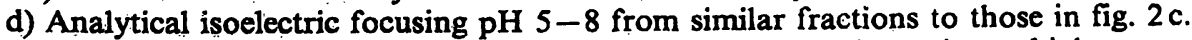

e) Cellulose acetate electrophoretic pattern of serum sample having a high concentration of creatine kinase-BB (total creatine kinase $75 \mathrm{U} / 1$ ) and a residual activity of $76,5 \mathrm{U} / \mathrm{l}$ using inhibiting anti-creatine kinase-M.

f) Analytical isoelectric focusing $\mathrm{pH} 3.5-9.5$ of the same sample as in fig. $2 \mathrm{e}$. 


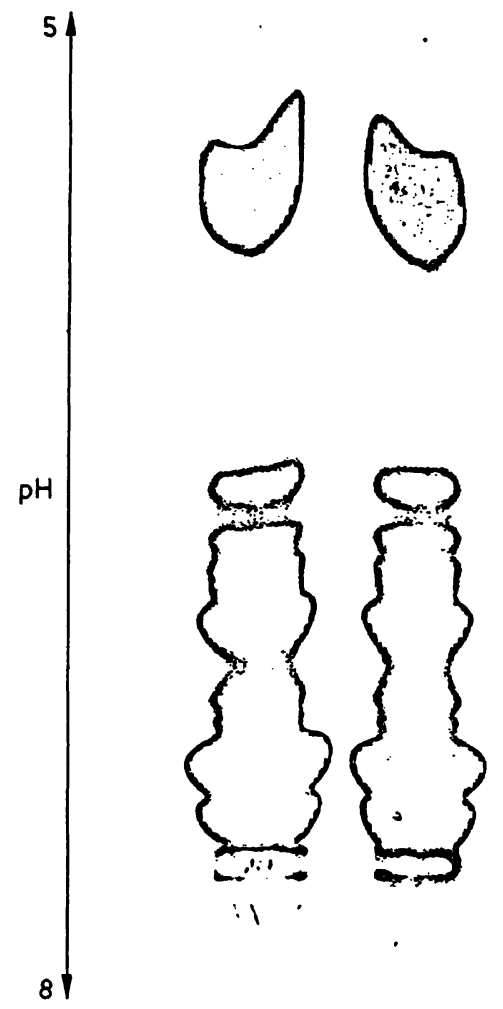

Fig. 3. Heterogeneity of cytosolic creatine kinase extracted from a human papillary muscle shown in duplicate by analytical IEF on Isogel-agarose in the $\mathrm{pH}$ range 5-8. The muscle was obtained during open-heart surgery for mitral valve replacement.

The heterogeneity of creatine kinase in human myocardial mitochondria using thinlayer isoelectric focusing on agarose

The samples $1-5$ shown in figure 4 correspond to the supernatant obtained after consecutive washing of the mitochondrial fraction. The mitochondrial creatine kinase was extracted overnight with 83 $\mathrm{mmol} / \mathrm{l}$ phosphate buffer and centrifuged at $100000 \mathrm{~g}$. The sediment obtained was resuspended in the same extraction buffer, sonicated for one minute with an interval of 0.5 minute and then centrifuged as stated above.

The washing samples and the two mitochondrial extracts were applied to thin-layer isoelectric focusing on Isogel agarose using Ampholine $\mathrm{pH} \mathrm{5-8.} \mathrm{The}$ zymogram demonstrates that, in contrast to both sample A (cytosol) and the washing samples, both mitochondrial extracts contain additional variants with increasing alkaline isoelectric points migrating in the direction of the cathode. No adenylate kinase activity was observed in the two controls described in figure $1 \mathrm{c}$ and $1 \mathrm{~d}$.

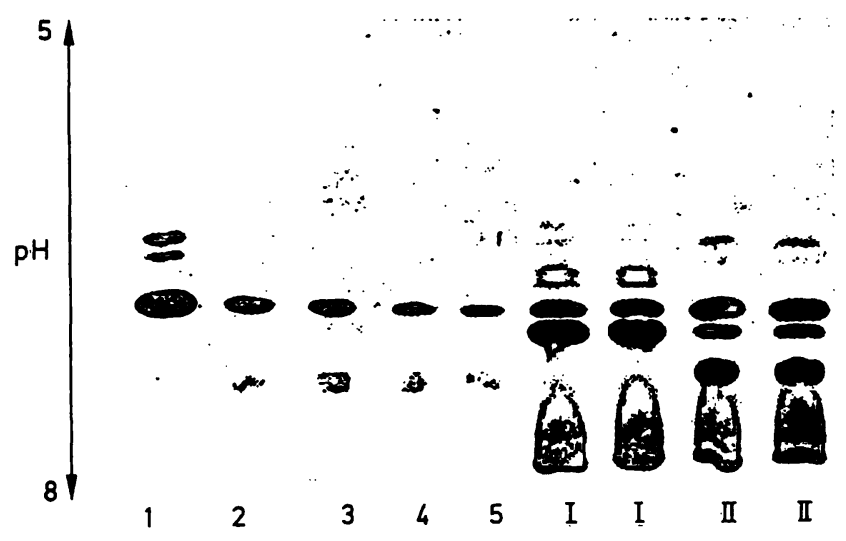

Fig. 4. Creatine kinase patterns of the supernatants obtained after consecutive washing of the mitochondrial fraction $(1-5)$ and duplicate application of two different mitochondrial creatine kinase extractions I and II, by analytical IEF on Isogel agarose (pH 5-8). Extraction I was taken in $83 \mathrm{mmol} / 1$ phosphate buffer and extraction II was obtained by ultrasonic treatment of the sediment from fraction $I$.

To emphasize the heterogeneity of mitochondrial creatine kinase, a further isoelectric focusing on agarose-IEF using Pharmalyte $\mathrm{pH}$ 6.5-9 was used as described by the manufacturer, supplemented with $2.5 \mathrm{mmol} / 1$ 2-mercaptoethanol and stained as described above.

The use of the $6.5-9 \mathrm{pH}$ range allowed the resolution of a more heterogeneous mitochondrial creatine kinase spectrum than those observed in the $5-8 \mathrm{pH}$ range (fig. 5). In the alkaline region, sample $B$ (cytosol) showed a heterogeneity similar to that obtained in the mitochondrial extract. In contrast to the 0.1 $\mathrm{mol} / \mathrm{l}$ cytosol and the mitochondrial extract, the 0.01 $\mathrm{mol} / \mathrm{l}$ cytosol demonstrates no heterogeneity in the alkaline region. This is the same behaviour as found in the $\mathrm{pH}$ range $5-8$.

The isoelectric focusing of mitochondrial creatine kinase with a pH-gradient column

The human mitochondrial creatine kinase was isoelectrofocused with a $\mathrm{pH}$ range of 5-9 in order to grossly localize this enzyme according to the method described above.

The fractions obtained were analysed for total creatine kinase activity, residual activity after creatine kinase-M immunoinhibition and by analytical isoelectric focusing.

The distribution pattern of mitochrondrial creatine kinase activity measured by total creatine kinase and immunoinhibition tests is demonstrated in figure 6 . 


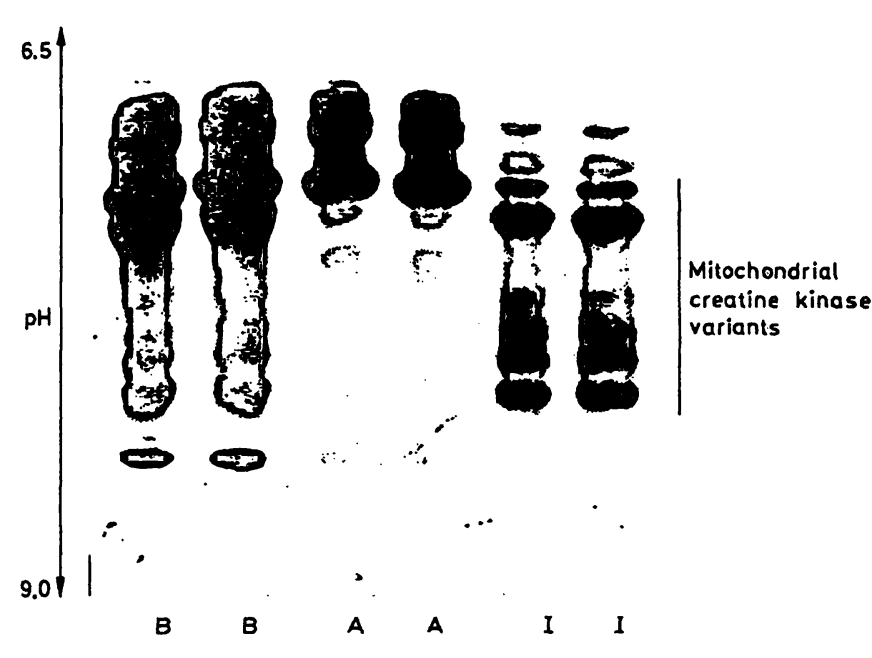

Fig. 5. Migration pattern of creatine kinase variants from human myocardial cytosol and mitochondria by analytical IEF on agarose-EF using pharmalyte $\mathrm{pH}$ 6.5-9. Samples $A$ and $B$ are the same as in fig. 1 and sample I the same as in fig. 4.

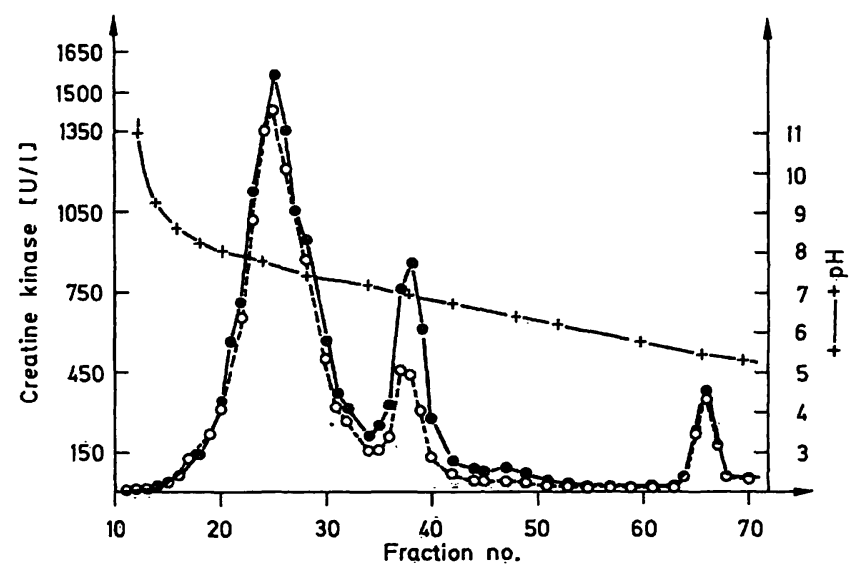

Fig. 6. Elution pattern of the mitochondrial creatine kinase variants from the electrofocusing column using Ampholine pH-range 5-9. The fractions were eluted with the aid of a peristaltic pump at a flow rate of $1 \mathrm{ml} / \mathrm{min}$. $0-0=$ total creatine kinasé, $0-0=$ residual activity using inbibiting anti-creatine kinase- $\mathrm{M},+-+=\mathrm{pH}-$ gradient.

It can be seen that in most fractions the creatine kinase activity was not inhibited by anti-creatine kinase-M. Maximal inhibition (50\%) was observed in fractions $36-38$ with isoelectric points of $7.0,6.95$ and 6.86 .

The analysis of the eluted fractions by IEF on agarose resulted in the pattern shown in figure 7. Different active creatine kinase bands with similar isoelectric points as compared to the original column eluates were observed.

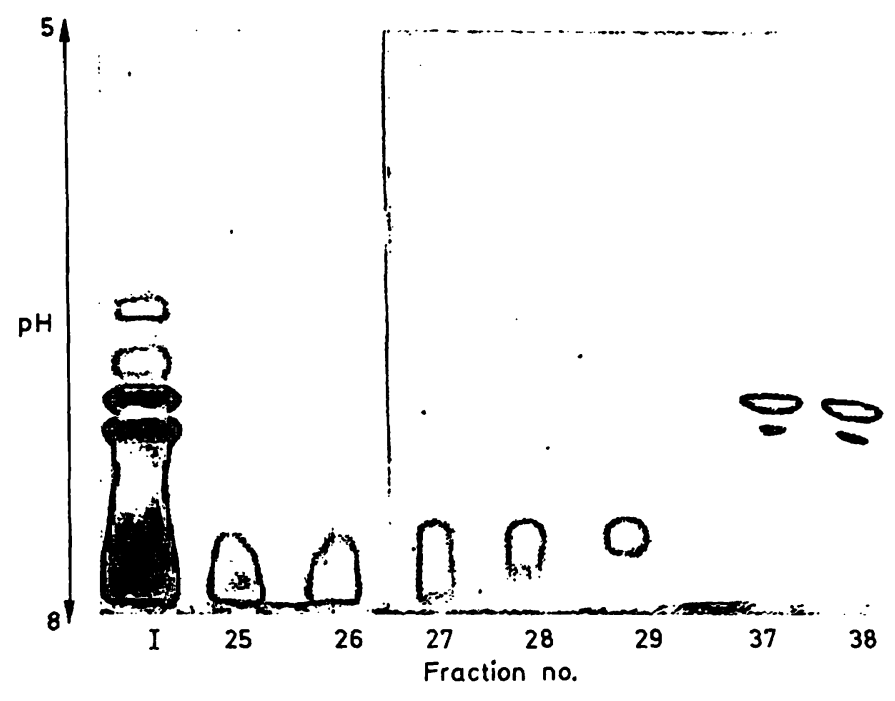

Fig. 7. IEF zymogram on Isogel-agarose obtained from special fractions of the Ampholine column eluates in fig. 6 . The zymogram was stained using nitroblue tetrazolium and meldola blue.

The agarose electrophoresis of fractions $21-32$ and $36-38$ resulted in representative patterns shown in figure 8 . Each of fractions $21-26$ revealed two distinct bands moving towards the cathode. The band with more activity moved faster towards the cathode than the one with less activity. On the other hand each of fractions $27-32$ showed only one band moving faster towards the cathode. In contrast to these bands, fractions $36-38$, which showed a $50 \%$ inhibition when treated with anti-creatine kinase-M, contain one band migrating towards the anode similar to creatine kinase-MM.

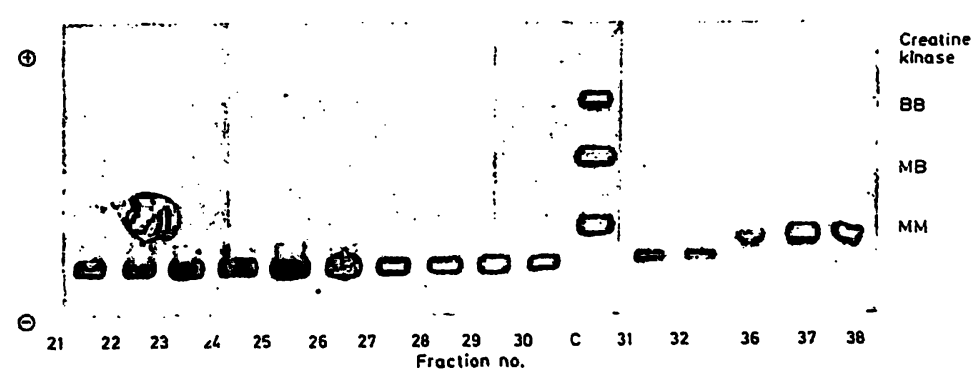

Fig. 8. Electrophoretic pattern from different Ampholine column eluates. Electrophoresis was performed on agarose and stained as in the analytical isoelectric focusing method.

$\mathrm{C}=$ Control (CPK-Isotrol). 
Estimation of Michaelis constants $\left(K_{\mathrm{m}}\right)$

For the estimation of $K_{\mathrm{m}}$ values for both creatine phosphate and ADP the standard assay (reverse reaction) was used. The $K_{\mathrm{m}}$ values for each substrate were calculated by graphical analysis (Lineweaver-Burk plot) of the initial velocities measured by varying the concentration of one substrate with respect to the fixed, saturating concentration of the other substrate.

Figure 9 summarizes the results for different mitochondrial creatine kinase variants separated by isoelectric focusing. The $K_{\mathrm{m}}$ values of the different mitochondrial variants were plotted against their isoelectric points. Compared with creatine kinase variants with low isoelectric points, creatine kinase variants with high isoelectric points have lower $K_{\mathrm{m}}$ values for both creatine phosphate and ADP.
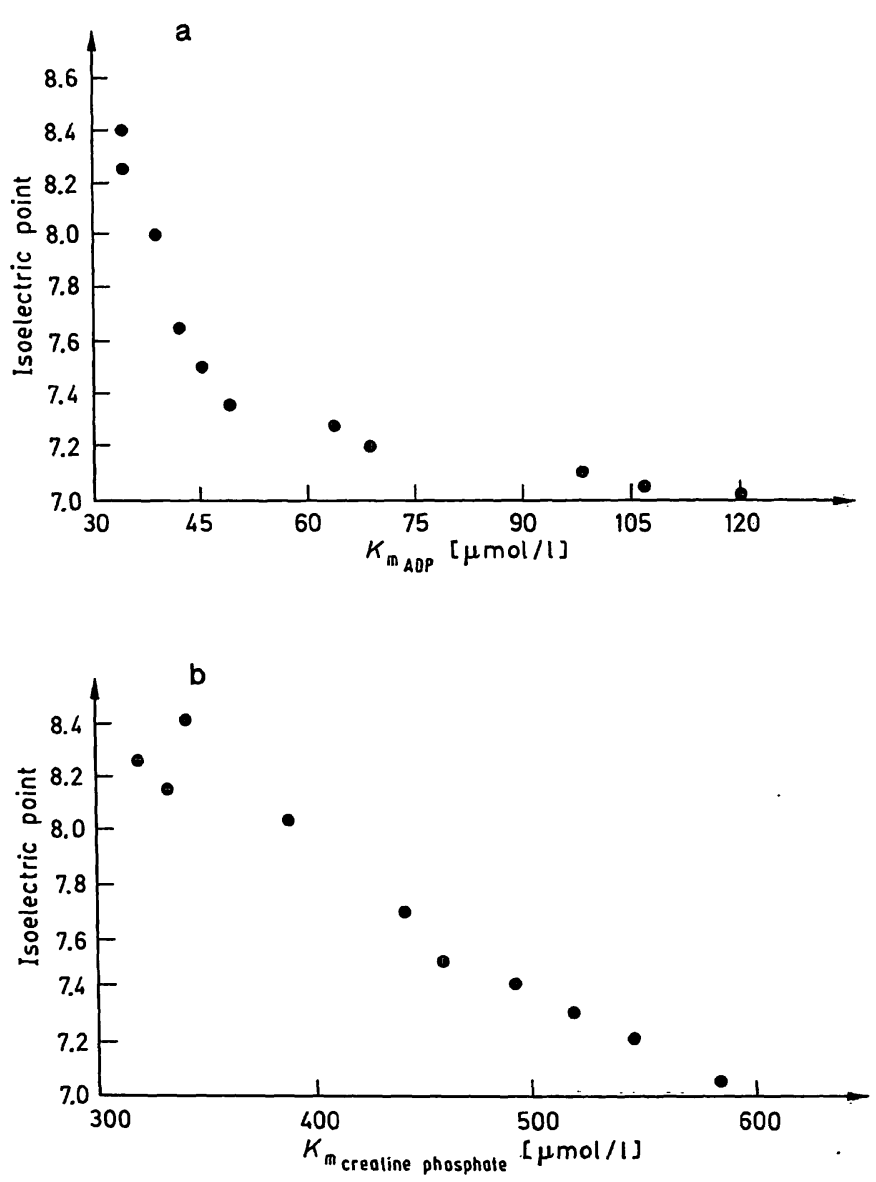

Fig. 9. a) Relationship between isoelectric points (IP) of mitochondrial creatine kinase variants as determined by IEF and their respective $K_{\mathrm{m}}$ values for ADP.

b) Relationship between isoelectric points (IP) of mitochondrial creatine kinase variants as determined by IEF and their respective $K_{\mathrm{m}}$ values for creatine phosphate.

\section{Discussion}

The apparent creatine kinase pattern from the human cardiac cytosol and mitochondria obtained by electrophoresis is in agreement with other reports (5-6, 11).

A ten-fold increase in the molarity of tris- $\mathrm{HCl}$ of the cytosol fractions results in the elution of creatine kinase isoenzymes with different patterns, as shown by analytical IEF (fig. 1). Cytosol B has more multiple forms of creatine kinase with alkaline isoelectric points than cytosol A. This difference could be explained by the fact that the nonchaotropic salts, like phosphates, potassium chloride (19) and glycine-tris$\mathrm{HCl}(20)$, extract proteins that are losely bound to the outer surface of the inner mitochondrial membrane.

The elution of the bands (fig. 2) and their measurement for total creatine kinase and residual activity reveals that the more cathodic bands were not inhibited,while others were partly, or completely inhibited by anti-creatine kinase-M. The electrophoretic separation of the eluted fractions shows two mitochondrial bands migrating cathodically to creatine kinase-MM in the range indicated by 1 . The positions indicated by 2, 3 and 4 reveal only creatine kinase-MM. In fraction 5 we observed creatine kinase-MB and a low creatine kinase-BB activity. These data confirm further that all bands were true creatine kinase activities.

Our findings contradict recent data indicating that only one type of the creatine kinase-MM and creatine kinase-MB isoenzyme is present in the cytoplasm of the human skeletal and heart muscle cell (21). The reason for this contradiction could be either poor sensitivity of the methods used, or inactivation of creatine kinase isoenzymes, since creatine kinase isoenzymes undergo reversible and irreversible inactivation in response to oxidation and temperature, respectively $(22,23)$. Using polyacrylamide, some authors were unable to detect many forms of creatine kinase in cardiac tissue extracts $(21,24)$. This could be due to the presence of persisting free radicals generated by ammonium persulphate. Ammonium persulphate has a strong oxidizing property $(25,26)$, which might inactivate these forms. This fact is supported by the finding that ammonium persulphate, as a polymerizing agent, caused the inactivation of yeast enolase (27).

However, the use of agarose which is chemically inert, enabled us to detect slightly elevated creatine kinaseMB activities (6 U/1) within 30 minutes, in contrast to some authors (24) who used polyacrylamide and were only able to detect highly elevated creatine kinase-MB activities after 3 hours. 
To prove the heterogeneity of creatine kinase the following tests were performed:

1. The possibility of creatine kinase heterogeneity induced by the IEF procedures could largely be ruled out by the ability of refocusing specific multiple forms without the appearance of other forms (fig. 7). For further exclusion of artefact formation in IEF, (28) different commercial ampholytes (from LKB and Pharmacia) were used with different $\mathrm{pH}$-gradients and different modes of sample application (anodal and cathodal) either on gels of agarose and polyacrylamide or columns. In each case identical heterogeneity patterns were seen.

2. Furthermore, the direct application of cryostat sections $(10 \mu \mathrm{m})$ of muscle biopsies to analytical IEF on agarose shows a creatine kinase pattern which is identical to that observed in the extracts from the respective tissues.

3. To eliminate sulphydryl group oxidation as a source of the enzyme heterogeneity, the homogenizing buffer and the support media used in the isoelectric focusing methods described above were supplemented with dithiothreitol or 2-mercaptoethanol. Denaturation of the post mortem samples by proteolysis seems to be unlikely because the samples were obtained within 4 hours after death. The similarity of the results given by both cytosol $\mathrm{A}$ and papillary muscle confirms this fact, since the papillary muscle was immediately extracted and further treated like cytosol A.

4. The application of analytical isolectric focusing to heart tissue extracts obtained from ox, rat, and mouse showed that creatine kinase, independent of species, is an enzyme of many forms. The multiple forms from an individual species have different isoelectric points from those of other species (unpublished data).

5. The titration curves obtained for both cytosolic and mitochondrial fractions confirm the heterogeneity of creatine kinase in these fractions. We believe that the heterogeneous forms of creatine kinase in both cytosolic and mitochondrial fractions are unlikely to arise by artefacts or common protein modifications.

These forms are possibly the products of multiple, but closely related genes as postulated by Rosenberg et al. (29).

They are unlikely to be MM sub-bands or mitochondrial sub-bands arising from alternative conformations of single subunit types, since the direct application of tissue sections to IEF did not reveal a single homogeneous band as would otherwise be expected.
We report here for the first time that creatine kinase located in human mitochondria exists in multiple forms which can be separated by isoelectric focusing. Extensive washing of the mitochondria with nonionic extraction medium minimizes possible contamination by creatine kinase located in the cytoplasm. Treatment of such mitochondrial preparations with phosphate buffer leads to further release of creatine kinase. It is not surprising that treatment of extracted mitochondria by sonication results in the further release of mitochondrial creatine kinase, since several authors have found that phosphate did not release more than 40 to $50 \%$ of the creatine kinase activity $(2,30)$. In addition Iyengar \& Iyengar $(20)$ demonstrated that $50 \%$ or more of beef heart mitochondria creatine kinase were firmly anchored to the inner membrane. The application of mitochondrial extracts to both cellulose acetate and agarose electrophoresis reveals two creatine kinase forms with similar electrophoretic behaviour as already described $(5-6,11)$.

A further analysis of extracted mitochondrial creatine kinase by analytical IEF on isogel agarose using Ampholine pH 5-8 or IEF agarose with Pharmalyte pH 6.5-9.0 demonstrates that this enzyme exists in multiple forms, with isoelectric points differing from those found in cytosol A.

Further evidence for the heterogeneity of this enzyme was given by the density-stabilized $\mathrm{pH}$-gradient on the IEF column. Further analysis of these fractions by analytical IEF on Isogel showed different bands with different isoelectric points similar to those observed in the original mitochondrial extract (fig. 4) focused with the same methods, although the IEF on the pH-gradient column is characterized by less resolution than the analytical IEF.

The fact that most of the multiple forms of mitochondrial creatine kinase found here were not inhibited by anti-creatine kinase-M, confirms previous findings concerning the dimer molecule described by several authors $(5-6,11)$.

Analysis of these fractions by electrophoresis showed two cathodic bands, the major band migrating faster than the minor band relative to creatine kinase-MM (fig. 8). Furthermore, we were able to demonstrate both mitochondrial forms by electrophoresis, in contrast to previous findings where only one form (creatine kinase-M red) was found in column eluates (6).

The fractions with IP $6.85-7.0$, which showed $50 \%$ inhibition with anti-creatine kinase- $M$, demonstrate one band migrating similarly to creatine kinase-MM. These fractions were unlikely to be creatine kinaseMM from the cytosol, since these forms were released after phosphate extraction and ultrasonic treatment. 
In addition, the creatine kinase-MM eluted from the cytosol B (fig. 1) was completely inhibited by anticreatine kinase-M. Perhaps the mitochondria contain creatine kinase variants which produce an isoelectric focusing pattern similar to that found in cytosol.

The cross-reactivity with anti-creatine kinase-M could be due to the non-specificity of the polyclonal antibody which might have additional affinity for such mitochondrial forms besides creatine kinaseMM. This could explain why several authors were not able to find such forms of creatine kinase-MiMi by both electrophoresis and immunoinhibition in the serum of patients with severe myocardial damage (15).

With regard to the physiological function of mitochondrial creatine kinase, it has been proved that ATP generated by oxidative phosphorylation in the matrix of the mitochondria is a substrate for the formation of creatine phosphate (31). Further, the affinity of mitochondrial creatine kinase for ADP and creatine phosphate is far higher than for ATP and creatine (10). However, the results summarized in figure 9 show that the different variants of mitochondrial creatine kinase have different affinity for both creatine phosphate and ADP.

Mitochondrial variants with similar isoelectric points in the mitochondrial bands described by other authors (6), have similar $K_{\mathrm{m}}$ values. Furthermore, variants with high isoelectric points show high affinity towards their substrates. Whether the occurrence of many mitochondrial variants is related to creatine phosphate energy transport, especially under the concept of functional enzyme localization, remains to be clarified.

\section{References}

1. Hall, N., Addis, P. \& DeLuca, M. (1977) Biochem. Biophys. Res. Comm. 76, 950-956.

2. Jacobus, W. E. \& Lehninger, A. L. (1973) J. Biol. Chem. 248, 4803-4810.

3. Sobel, B. E., Shell, W. E. \& Klein, M. S. (1972) J. Mol. Cell Cardiol. 4, 367-380.

4. Jacobs, H., Heldt, H. W. \& Klingenberg, M. (1964) Biochem. Biophys. Res. Comm. 16, 516-521.

5. Blum, H., Weber, B., Deus, B. \& Gerok, W. (1978) HoppeSeyler's Z. Physiol. Chem. 359, 1058.

6. Wevers, R. A., Mul-Steinbusch, M. W. F. J. \& Soons, J. B. J. (1980) Clin. Chim. Acta 101, 103-111.

7. SiragEldin, E., Gercken, G. \& Voigt, K. D. (1983) In: Electrophorese forum '83 (Radola, B. J., ed.), pp. 217-225, Technische Universität München.

8. George, S., Ishikawa, Y., Perryman, M. B. \& Roberts, R. (1984) J. Biol. Chem. 259, 2667-2674.

9. Guslits, B. G. \& Jacobs, H. K. (1983) Clin. Chim. Acta $130,55-69$.

10. Hall, N., Addis, P. \& DeLuca, M. (1979) Biochemistry 18 , $1745-1751$

11. Kanemitsu, F., Kawanishi, I. \& Mizushima, J. (1982) Clin. Chim. Acta 119, 307-317.

12. Desjardins, P. R. (1982) Clin. Chim. Acta 121, 67-78.

13. Grace, A. M., Perryman, M. B. \& Roberts, R. (1983) J. Biol. Chem. 258, 15346-15354.

14. Roberts, R. \& Grace, A. M. (1980) J. Biol. Chem. 255, $2870-2877$.

15. Lang, H., ed. (1981) Creatine kinase isoenzymes, SpringerVerlag, Berlin, Heidelberg, New York.

16. German Society for Clinical Chemistry (1977) J. Clin. Chem. Clin. Biochem. 15, 255-260.

17. SiragEldin, E., Gercken, G., Harm, K. \& Voigt, K. D. (1985) J. Clin. Chem. Clin. Biochem. 23, 241-248.

18. LKB Instruction 1818-A, LKB-Produkter AB, Bromma.

19. Klingenberg, M. \& Pfaff, E. (1966) Regul. Metab. Processes Mitochondria, Proc. Symp. 1965 17, 180-201.

20. Iyengar, M. R. \& Iyengar, C. L. (1980) Biochemistry 19 , 2176-2182.

21. Wevers, R. A., Delsing, M., Klein Gebbink, J. A. G. \& Soons, J. B. J. (1978) Clin. Chim. Acta 86, 323-327.

22. Morin, L. G. (1977) Clin. Chem. 23, 646-652.

23. Morin, L. G. (1977) Clin. Chem. 23, 205-210.

24. Chapelle, J. P. \& Heusghem, C. (1980) Clin. Chem. 26, $457-462$.

25. Righetti, P. G. (1983) Isoelectric focusing: theory, methodology and applications, Elsevier Biomedical Press, Amsterdam, New York, Oxford.

26. Bosisio, A. B., Loeherlein, C., Snyder, R. S. \& Righetti, P. G. (1980) J. Chromatogr. 189, 317-330.

27. Brewer, J. M. (1967) Science 156, $256-257$.

28. Gärtner, R., Henze, R., Horn, K., Pickardt, C. R. \& Scriba, P. C. (1981) J. Clin. Endocrinol. Metab. 52, 657-664.

29. Rosenberg, U. B., Eppenberger, H. M. \& Perriard, J.-C. (1981) Int. J. Biochem. 116, 87-92.

30. Farrell, E. C., Baba, N., Brierley, G. P. \& Grümer, H.-D. (1972) Lab. Invest. 27, 209-213.

31. Saks, V. A., Lipina, N. V., Smirnov, V. N. \& Chazov, E. I. (1976) Arch. Biochem. Biophys. 173, 34-41.

Dipl.-Biochem. E. SiragEldin Abteilung für Klinische Chemie der Medizinischen Klinik

Universitäts-Krankenhaus Eppendorf

Martinistraße 52

D-2000 Hamburg 20 
ORIGINAL IKA Spitzenqualität aus dem Schwarzwald

\section{ieispiel:}

\section{KA-VIBRAX VXR} Icht Schüttler in Einem:

lit diesem elnen Basisschüttler IBRAX ${ }^{\circledR}$-VXR können Sie zumindest cht verschiedene Schütteloperatioen durchführen.

intscheiden Sie sich anhand ires Anwendungsfalles und rählen den oder die ichtigen aus dem roBen IKA-Schüttler lufsatzproramm aus. $\mathrm{KA}^{\oplus}$ denkt für eine Kunden.

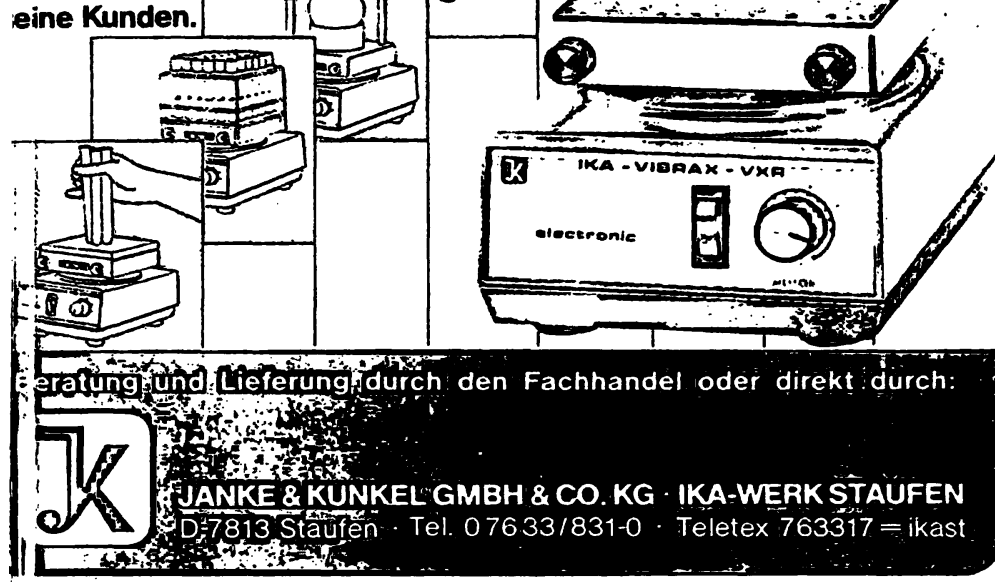

Wir stellen aus auf der ANALYTICA '86

in München, Halle 2, Stand-Nr. B 12/C 9

\section{M. Goldberg - M. Werner (Editors)}

\section{Selected Topics in Clinical Enzymology}

Proceedings (selected) of the Third International Congress of Clinical Enzymology Salzburg, Austria, September 6-9, 1981

1983. $17 \mathrm{~cm} \times 24 \mathrm{~cm}$. XVIII, 362 pages. With numerous illustrations. Hardcover. DM 160,-二; approx. USS-\$72.75

ISBN 31100960

This book contains 27 contributions providing comprehensive cover of the application of enzymes in four important aspects of Clinical Enzymology:

Enzymes in Cancer - Enzymes in Blood Pressure Regulation - Enzymes in Blood Coagulation - Enzymes in Diseases of Heart and Muscle.

By means of carefully selected reviews and original articles, the reader is brought up to date with the latest advances in these topics. An Author Index and a Comprehensive Subject Index are included.

\section{LIPIDOPHOR}

\section{Optimale Lipoproteindiagnostik} auf einen Blick

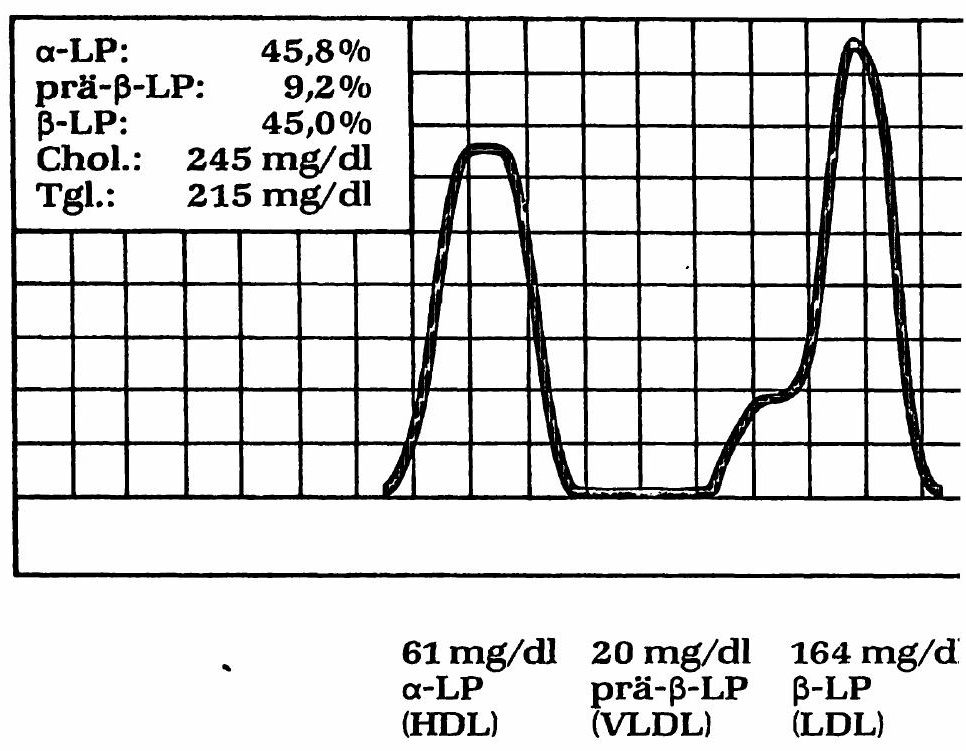

OIn der Grauzone (Chol. 200-300 mg/dl, TG $>200 \mathrm{mg} / \mathrm{dl}$ ) ist die Quantifizierung von HDL und LDL zur Abschätzung des individuellen Risikos wichtig.

ODie quantitative Lipoprotein-Elektrophorese ist die einzige Methode, die HDL und LDL in einem Arbeitsgang auck bei TG Werten $>300 \mathrm{mg} / \mathrm{dl}$ richtig bestimmt.

ODie übersichtliche Dokumentation erleichtert die Auswertung, Veränderungen im Lipoprotein-Status werden sofort erkennbar.

\section{TMMUNO}

Die Spezialisten füir differenzierte Lipoproteindiagnostik

Immuno GmbH Slevogtstraße 3-5 6900 Heidelberg Telefon (06221) 397-1 


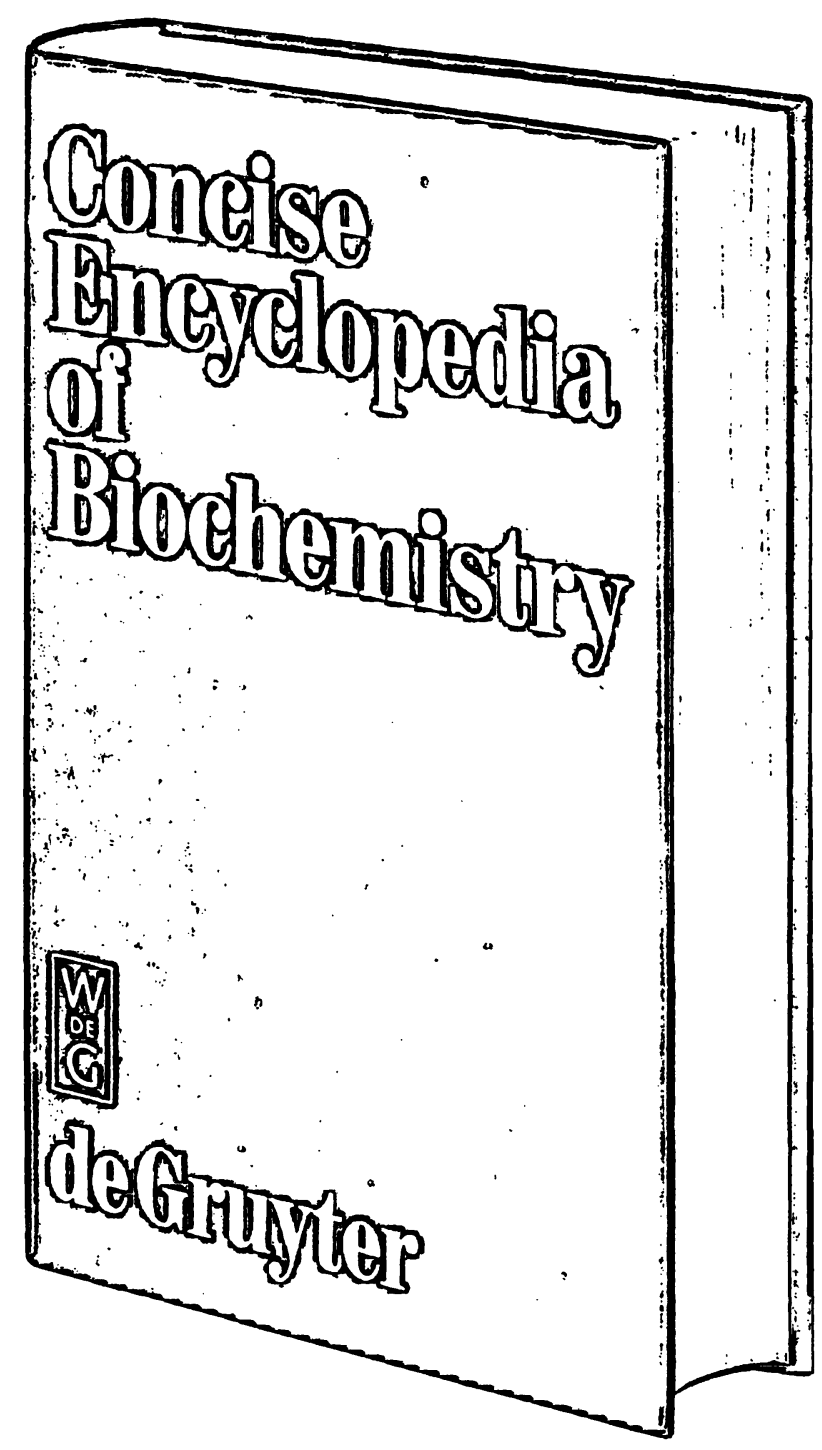

Edited by

Thomas Scott and Mary Brewer

2nd printing with corrections.

1983. $14,0 \mathrm{~cm} \times 21,5 \mathrm{~cm}$.

VI, 519 pages.

Approx. 650 illustrations.

Hardcover. DM 78,-; US \$34.95

ISBN 3110078600

Prices are subject to change without notice

The Concise Encyclopedia of Biochemistry, with more than 4,200 entries, is the foremost collection of current information in this rapidly expanding field. The contents are complemented by numerous structural formulas, metabolic pathways, figures and tables. All those interested in or working in the field of Biochemistry and Biology (Life Sciences), will profit from the information contained in this encyclopedia.

This truly remarkable book is an essential reference for Biochemists, Clinical Chemists, Clinical Biochemists, Clinicians, Medical Researchers and Experimental Biologists. It will also serve as a very useful source of information for students. 